International Journal on Emerging Mathematics Education (IJEME)

Vol. 1, No. 2, September 2017, pp. 185-192

P-ISSN: 2549-4996, E-ISSN: 2548-5806, DOI: http://dx.doi.org/10.12928/ijeme.v1i2.6698

\title{
Filling the Gap between Theory and Action through a Model for Classroom Inquiry
}

\author{
Abolfazl Rafiepour \\ Shahid Bahonar University of Kerman, Kerman, Iran \\ e-mail: drafiepour@gmail.com
}

\begin{abstract}
Artikel ini melaporkan sebuah investigasi tentang program pengembangan profesi guru sekolah menengah pertama di Iran di mana tujuh puluh guru matematika terlibat di dalamnya. Pada program tersebut, lesson study dan penelitian tindakan digunakan untuk membangun model classroom inquiry. Tujuan yang pertama dan utama dari model ini adalah untuk mengisi kesenjangan antara teori dan tindakan. Hasil penelitian ini menunjukkan bahwa mengkombinasikan lesson study dengan penelitian tindakan adalah suatu hal yang mungkin. Temuan penelitian ini juga menunjukkan bahwa penggunaan model classroom inquiry dapat mengurangi kesenjangan antara teori dan tindakan. Akhirnya, artikel ini diakhiri dengan memperkenalkan beberapa kesulitan yang terjadi dalam mencapai keberhasilan program pengembangan profesi guru tersebut.
\end{abstract}

Kata Kunci: penelitian tindakan, lesson study, teori, tindakan, classroom inquiry

\begin{abstract}
This paper reports an investigation about lower secondary teacher professional development program in Iran that seventy teachers of mathematics participate on that. In this program, lesson study and action research are used to create a model for classroom inquiry. The first and important purpose of this model was to filling the gap between theory and action. Results of this study show that it is possible to combine lesson study and action research. Finding of this study also show that using the model for classroom inquiry can be helpful in decreasing the gap between theory and action. Finally, paper will be finish by introducing some obstacle that occurred within the accomplishment of the teacher professional development program.
\end{abstract}

Keywords: action research, lesson study, theory, action, classroom inquiry

How to Cite: Rafiepour, A. (2017). Filling the gap between theory and action trough a model for classroom inquiry. International Journal on Emerging Mathematics Education, 1(2), 185-192. http://dx.doi.org/10.12928/ijeme.v1i2.6698

\section{INTRODUCTION}

This paper has aimed to introduce a model for classroom research which will be conducted by teachers themselves. In this paper, a model for classroom inquiry will be developed in order to enhancing teacher knowledge at in-service teacher training for the lower secondary level, in Iran. So, it will be good idea to discuss shortly about Iran educational system and teacher education specially with focusing on lower secondary level.

\section{Iran Educational System}

The current educational system in Iran consists five years of elementary, three years of guidance cycle, four years of secondary education of which the first eight years of schooling are compulsory (Gooya, 2007). So, Iran educational system is 5-3-4 model. Students come to school at age 6 and finished primary school at age 10. Lower secondary level (or guidance cycle) offer for students aged 11-13. After lower secondary school, student study grade 9 and in the end of this grade, student divided by two streams: 
academic and vocational. In the academic branch, there are three major area of study: mathematics and physics, experimental science and literature and humanities (Kiamanesh, 1997). Vocational education provides skill development and training for students wishing to pursue specific technical careers. Vocational education divided into three areas of study: technical, Agricultural, and vocational (Kiamanesh, 1997).

Teacher Training Program (Pre-Service \& In-Service)

There are two different centres for teacher training. One of them is university that works under the jurisdiction of the Ministry of Science, Research, and Technology which train secondary school teachers. Second one is teacher education centre that works under the jurisdiction of the Ministry of education which train elementary and lower secondary (or guidance cycle) teachers. There are several centres, which perform teacher training in primary and lower secondary with different purposes, but because of concentration of this study on lower secondary school, I just continue discussion about lower secondary school teacher training.

Certification of mathematics teachers in lower secondary level consist of two-year study after secondary school in teacher education centre. Both primary and guidance teacher education centres offer wide range of courses which lead to the award of an Associate Diploma. These centres offer courses in 12 streams as follows: mathematics, experimental science, physical science, English, technical and vocational education, social science, primary education, Persian literature, counselling, Islamic ethics and Arabic language, Art, and Special education (Kiamanesh, 1997). Each teacher is supposed to specialize in only one stream.

Pre-service program for teacher education is consist of content knowledge and some pedagogical; courses. These pedagogical courses cover about 20 percent of the program. Furthermore, for keeping teacher, up to date, there special in-service teacher education, that assign by ministry of education in each school year. Usually, there is two program consist around 40 hours for each year. For this year, writer with a group of master students in mathematics education, conduct the teacher program. Details of this program will be appearing in the methodology section. Before the beginning this in-service course, some mathematics teachers ask me to create a practical course than theoretical one. Indeed, their request back to their last experiments in such classes which they find course useless. So, I decide to develop a model for classroom research in order to filling the gap between theory and practice. For doing that I consider lesson study and action research and develop a model for enhancing teacher knowledge and decreasing distance between theory and practice. It is necessary to remind about action research in Iran educational system. Ministry of education from 1996 decides to encourage and support teachers and other staff to conduct an action research. Within this school year we pass $14^{\text {th }}$ action research set in national level. In the end of each year, ministry of education select some of these action researches in the local and national level and reward them. So, with above comment, two below research questions showing the right way in current study are (1) to what extent using the model for classroom inquiry, decreasing the gap between theory and action? (2) What are benefits and obstacles of using this model for teacher training program?

Two areas of literature informed this study: lesson study and action research. Although action research and Lesson study have different origin, but in some extent both of them have similar aspect. For example, Sanders (2009) considers lesson study and action research as the same thing in microcosm level. Like sanders (2009) some researchers classify lesson study as a form of action research (Taylor, Anderson, Meyer, Wagner, \& West, 2005; Yoshida, 1999). Indeed, they consider Lesson study as a subset of action research. But, in the other hand, some researchers believe that lesson study has a little bit different with action research, so they try to integrate these two approaches together (Keeney et al., 2002; Taylor, 2001). For example, Taylor (2001) introduced lesson study as 
part of a sequence of experiences that leads to action research and In her study, she ask students to writing an action research project about their lesson study experience.

In current study, like Taylor (2001), I use both of action research and lesson study, for enhancing teacher professional development and ask them to writ an action research about their lesson study experience that designed in their group of teachers. Before continuing discussion, it will be good idea to have some controversy about lesson study and action research in separate paragraph.

Lesson study - jugyokenkyu- is a method of continual professional development that used in Japan for the first time. This method introduced by works of Yoshida (1999) and then with a book with title "Teaching Gap" (Stigler and Hiebert, 1999) to English speaking world. They (1999, pp. 112-116) summarize lesson study through eight steps: defining the problem (Step1); planning the lesson (Step2); teaching the lesson (Step3); reflecting and evaluating the lesson (Step4); revising the lesson (Step5); teaching (Step6); the revised lesson (Step7); reflecting and evaluating, and sharing results (Step8).

In the other hand, the origin of action research comes back to Kurt Lewin an American psychologist, in the mid-1940s (Kemmis and McTaggert, 1988). Although there are different type of definition and explanation for action research in the literature review but all of them have two most important principals: engaging with the action and improve that action (Chaichi, Gooya, Mehrabani, and Saki, 2006). The process of doing action research cycles consisting of four major phrases: planning, acting, observing and reflecting (McNiff, Lomax, \& Whitehead, 2003). The focus of all action research process in a broad sense is the action that teachers take in their classrooms to create new changes. The research process is a study of this new changes through systematic data collection and analysis these data. As we can see there are similar components with these two approaches: lesson study and action research.

However, in current study I use lesson study for starting point and ask teacher to write an action research report as a part of assessment in the teacher professional development program. So, I design below model for classroom inquiry and introduce it to teachers for starting their classroom research. This model has eight steps as below:

Step1: start from classroom teaching experiments;

Step2: finding a problem related to teaching/learning process;

Step3: study about problem that introduced in last step and explain desirable situation;

Step4: design a pattern for reaching to desirable situation;

Step5: teaching with new pattern;

Step6: observation and gathering more data about the situation after teaching with new pattern;

Step7: reflection about new pattern (Is it work?);

Step8: report action research.

One of the key features of the model for classroom inquiry was the role of reflection. Reflection was ready in all part of the process. In this model teachers have to work together in whole time of the course and cooperate with each other. Whole class discussion, group discussion and present to other colleagues are assumed in this model. In step 3 of the model, a team of mathematics educators working with teachers in group and help them to finding related papers, books and other materials. In step 7, if the new pattern work correctly and reach to desirable situation, then teachers move to next step and ready to write and publish their action research. If this new pattern doesn't work, then teachers come back to step 4 and designing a new pattern. This recurrent process that occur between step 4 and step 7 , represent the cyclic nature of lesson study and spiral nature of action research in the model. Finally, because of teachers' facilities in access and applying this model I put all of the steps of the model in a flowchart format as shown in Figure1. 


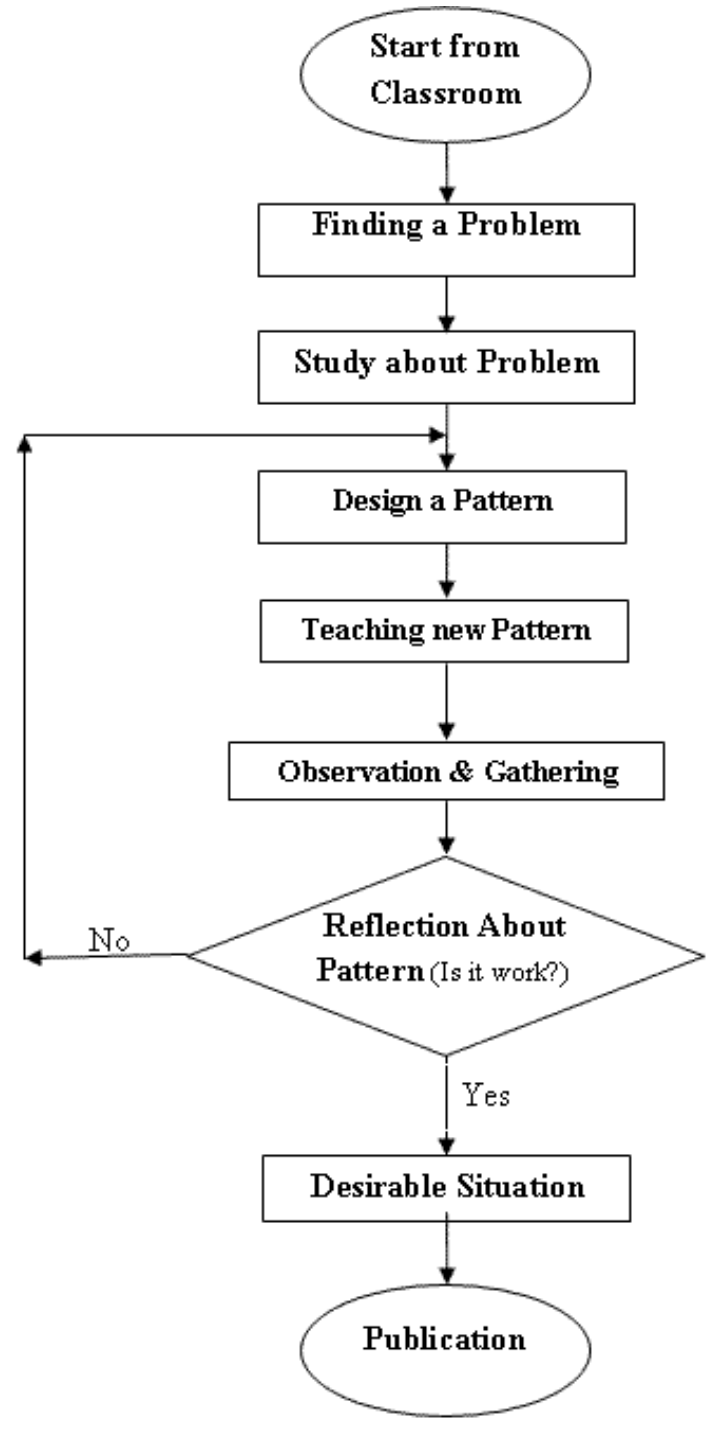

Figure1. Flowchart of model for Classroom Inquiry

\section{RESEARCH METHOD}

Seventy lower secondary school teachers participated in the professional development program. This program conducted within 8 weeks, each week 4 hours for every group. Forty teachers participate in the Tuesday every week and another thirty teachers participate in the program in the Friday every week. Teachers divided in group of five, when they engaged in working group. This program started in October 2016 and continued through February 2017.

In the first session, teachers complete a questionary. In this questionary, ask teachers to give details about their academic degree, teaching and research experience. This initial questionary includes some more items: (1) What is your expectation with in this professional development program? (2) What is a desirable teaching method for lower secondary math? (3) What you think about your ability in teaching lower secondary math? (4) What are you doing exactly when you confront with a challenge? (5) To what extent, have a reflection in your teaching experience?

Teachers, spend half of the first session to completing the initial questionary. In the next half of time in the first session, author of this paper, talk about brief history of lesson 
study and action research, and present flowchart of model for classroom inquiry to teachers. In each session, teachers work on one part of the flowchart of model for classroom inquiry. As an example, in the second session, teachers finding a problem from their classroom experience in their group. In this session teachers working on worksheet 1 that produced by instructor (Author of this paper). In this worksheet, there are different part consist of: the name of group, the name of group members, state the research problem, mathematical content related to this research problem, evidence for this research problem, characteristics of desirable situation in the case of this research problem. For every session teachers, complete a worksheet in their groups and then discuss about that in the group and whole class. In this process, every teacher, learn from other teachers and educator experience. Altogether, there are five worksheets in this study, that teachers complete them step by step. Finally, teachers collect their works in the action research format (McNiff, Lomax, \& Whitehead, 2003) and report it as a part of their assessment in the professional development program.

In this study, there are four resource of data collection procedure: initial questionary, final questionary, semi-instructed interview, action research reports produced by teachers. An open-ended questionary was administered on the last day of the program, in order to give an opportunity to teachers to reflect on whole of this program. Final questionary has some relation with initial questionary. For example, in the final questionary had been asked teachers: to what extent does this program complied with your expectation? There are more items in the final questionary like: (1) To what extent this program can fill the gap between theory and practice? (2) Which part did I enjoy the most? Which part disappointed me the most? (3) What is in my teaching experience as a result of this training program? (4) What are my secessions for future teacher training program?

For having extra deep information about the professional development program, had been conducted two interview. For data analysis process, grounded theory approach had been used (Strauss, and Corbin, 1998). I start to make sense of data by making interpretation. This process continued using open coding to discover categories. In the next section, preliminary results of this study are reported.

\section{RESULTS AND DISCUSSION}

Upon initial questionary, almost all teachers had bachelor degree in mathematics. About seventy percent of teachers have more than ten years of teaching experience in mathematics. About five percent of them had experience in doing some kind of research. One of them had a master degree in mathematics education and she do a research project as her thesis for master program. So, most of them didn't know much more about research in general sense, although all of them, hear about action research because of advertisement that had been distributed by ministry of education in every year about action research. Local office of education by same direction with ministry of education, encourage teachers and other staff to participate in the action research program. However, almost all teachers that participated on this teacher development program hadn't enough information for doing action research in their classroom setting. Furthermore, Initial questionary revealed those teachers' expectations from this professional development program. After categorization of teachers' response, the requisitions are (1) we want to developing our content and pedagogical knowledge; (2) we want to have communication with other teachers and teacher educator in actively manner; (3) we want to have different course than previous courses which discuss about theory and practice separately; (4) we are interesting to discuss about most important things that have strong relation with our teaching experiences;

Final questionary show teachers are so happy with in this teacher training program. 
They reach to their almost all aims in this program. Results of interview also support this satisfaction. Teachers said this program was successful to reconcile theory and practice. Most enjoyable part of the model for teachers was finding the relation between theory and practice and most disappointed part of the model was shortage of educational resource in Persian language. At the end of program all group of teachers report their work in the action research format. Table 1, indicates the title of six action research with sample sizes for the teacher and student engage on them.

Table 1. Sample of action research conducted by teachers

\begin{tabular}{clcc}
\hline$\#$ & \multicolumn{1}{c}{ Title of action research } & $\begin{array}{c}\text { \# of } \\
\text { teachers }\end{array}$ & $\begin{array}{c}\text { \# of } \\
\text { students }\end{array}$ \\
\hline 1 & $\begin{array}{l}\text { What are the difficulties of students in division of decimal } \\
\text { numbers? }\end{array}$ & 5 & 25 \\
2 & $\begin{array}{l}\text { How we can help students to do calculation with whole } \\
\text { number? }\end{array}$ & 5 & 24 \\
3 & $\begin{array}{l}\text { Why students couldn't solve story problems? } \\
4\end{array}$ & 5 & 25 \\
5 & $\begin{array}{l}\text { Investigation on students' misconceptions in square root? } \\
\text { What are the students' difficulties in common }\end{array}$ & 5 & 25 \\
6 & $\begin{array}{l}\text { denominator? } \\
\text { Investigation on students' problems in power problem? }\end{array}$ & 5 & 23 \\
\hline
\end{tabular}

\section{CONCLUSION}

Preliminary results show that it is possible to implement this model for classroom inquiry in professional development program. Within this program, teachers find some theories that related to their first-hand teaching experiment and become happy with integration theory and practice. As a result of this, pedagogical content knowledge (PCK) developed by teachers. After publication of these results in the action researches format, teachers of mathematics have access to good resource of PCK. This pedagogical content knowledge has an important role in the case of Iran, because teachers of mathematics in the pre-service teacher training have some courses in mathematics and some other courses in pedagogy and they haven't opportunity for combining them. Current teacher training program give such opportunity to teachers. According to Yoshida (2008) although the process of implementing lesson study seems simple on the surface level, but implement lesson study effectively is not an easy task. In this study, during teacher professional development program, some teachers are disturbed about other teachers' pungent critique in the whole class discussion. It seems to be an important issue that will be address in the future study. Another obstacle that occurred during administering the program was the shortage of previous similar research in literature review.

\section{REFERENCES}

Chaichi, P., Gooya, Z., Mehrabani, N., \& Saki, K. (2006). Assessing the goals of action research program in Iran. Seasonal Journal of Education, 85, 107-133.

Gooya, Z. (2007). Mathematics teachers' beliefs about the new reform in high school geometry in Iran. Educational Studies in Mathematics, 68, 331-347.

Keeney, M.A., Paganelli, S., Smith, J., Quinn, K., Krane, A., ..., Craven, K. (2002). Lesson study with action research: is the 4-column writing method 4 real? Paper presented at the Annual Meeting of the Mid-Western Educational Research Association (Columbus, OH, October 16-19, 2002).

IJEME, Vol. 1, No. 2, September 2017, 185-192 
Kemmis, S., \& McTaggart, R. (1988). The Action Research Planner (3rd ed.). Geelong, Australia: Deakin University Press.

Kiamanesh. A., \& Faghihi, F. (1997). Islamic Republic of Iran -Educational System-. In D. F. Robitaille (Ed.), National Contexts for mathematics and Science Education: An Encyclopedia of the Education Systems Participating in TIMSS (pp: 189-196). Vancouver, Ca: Pacific Educational Press.

McNiff, J., Lomax, P., \& Whitehead, J. (2003). You and Your Action Research Project (2nd ed.). London: Routledge Falmer.

Sanders, P. (2009). Lesson Study: An Effective School-Based Teacher Professional Learning Model for Teachers of Mathematics. In R. Hunter, B. Bicknell, \& T. Burgess (Eds.), Crossing divides: Proceedings of the $32^{\text {nd }}$ annual conference of the Mathematics Education Research Group of Australasia (Vol. 2). Palmerston North, NZ: MERGA.

Stigler, J.W., \& Hiebert, J. (1999). The Teaching Gap: Best Ideas from the World's Teachers for Improving Education in the Classroom. New York: Free Press.

Strauss, A.L. \& Corbin, J.M. (1998). Basics of qualitative research: Techniques and procedures for developing grounded theory (2nd edition). Newbury Park, CA: Sage.

Taylor, A.R., Anderson, S., Meyer, K., Wagner, M.K., \& West, C. (2005). Lesson study: A professional development model for mathematics reform. The Rural Educator, 26(2), 17-23.

Taylor, A. (2001). From lesson study to action research: Possibilities and perils. Paper presented to $25^{\text {th }}$ Annual International Conference of the Collaborative Action Research Network, England. 4 November, 2001.

Yoshida, M. (1999). Lesson Study: A Case Study of a Japanese Approach to Improving Instruction through School-Based Teacher Development. Unpublished Doctoral Dissertation, the University of Chicago, USA.

Yoshida, M. (2008). Exploring ideas for a mathematics teacher educator's contribution to lesson study: towards improving teachers' mathematical content and pedagogical knowledge. In D. Torish and T. Wood (Eds.), the international handbook of mathematics teacher education: tools and processes in mathematics teacher education. Rotterdam: Sense publisher. 
